\title{
Biochemical Studies of Energy Production in the Failing Human Heart*
}

\author{
Charles A. Chidsey, $†$ Eugene C. Weinbach, Peter E. Pool, and \\ ANDREW G. MORROW \\ (From the Cardiology Branch and the Clinic of Surgery, National Heart Institute, and the \\ Laboratory of Parasitic Diseases, National Institute of Allergy and Infectious \\ Diseases, Bethesda, Md.)
}

The defective myocardial performance responsible for the syndrome of congestive heart failure has been considered for many years to involve a biochemical abnormality. However, identification of this abnormality remains to be achieved. Muscle cell function is basically a process by which chemical energy is transformed into the mechanical work of myofibrillar shortening and force development. The presence of a biochemical abnormality in the failing cardiac muscle must therefore be sought either in the mechanism of energy production or in the mechanism of energy utilization by the contractile system. The present report is a study of energy production in the failing human heart.

Considerable evidence has accumulated to indicate that myocardial extraction of oxygen and of oxidizable substrates is not diminished in patients with congestive heart failure (1-3). These studies have not, however, provided evidence that the final supply of chemical energy to the contractile apparatus is normal. ATP, the immediate source of chemical energy utilized by muscle (4), is formed within the mitochondrion during the oxidation of substrates by the process of oxidative phosphorylation. The completeness with which the process of phosphorylation is coupled to that of oxidation determines whether or not the energy liberated in the oxidation of substrates becomes available for useful mechanical work by the contractile apparatus. A number of toxic agents have been shown to be capable of uncoupling electron transport and phosphorylation, both in vitro (5)

\footnotetext{
* Submitted for publication June 21, 1965; accepted September 23, 1965.

A partial report of this work was presented at a sectional meeting of the American Society for Clinical Investigation, May 2, 1965.

$\dagger$ Address requests for reprints to Dr. Charles A. Chidsey, Dept. of Medicine, University of Colorado School of Medicine, 4200 E. Ninth Ave., Denver, Colo.
}

and in vivo $(6,7)$, and one clinical syndrome, characterized by nonthyroid hypermetabolism and resulting from uncoupling of these two processes, has been identified by Luft and associates (8).

Mitochondrial function in the failing heart has previously been studied only in experimental animals, where the findings have been conflicting. Oxidative phosphorylation and the content of high energy phosphate compounds have been reported to be normal in some of these studies $(9-12)$, whereas in others defective energy production has been observed (13-17). Thus, it seemed evident that this problem, in the clinical syndrome of congestive heart failure, could be solved definitively only by studying mitochondrial function and morphology and the content of high energy phosphate compounds in human myocardial tissue. Accordingly, the present study was carried out with myocardial tissue removed at the time of cardiac operations from 25 patients with congestive heart failure. Mitochondria isolated from these tissues were shown to possess a high degree of structural and functional integrity, and the myocardial content of high energy phosphate compounds was not found to be reduced. We concluded, therefore, that there is no evidence for a biochemical abnormality of energy production in the failing human heart.

\section{Methods}

This type of investigation on viable human cardiac tissue is now possible because of the development and application of effective surgical methods for prosthetic replacement of cardiac valves. Papillary muscles were removed from 14 patients with heart failure; in 13 patients, muscles were obtained from the left ventricle at the time of removal of diseased mitral valves, and in one patient muscles were obtained from the right ventricle during excision of the tricuspid valve. In all patients rheumatic heart disease was responsible for the valvular deformity, and all were on maintenance digoxin. The patients, seven 
men and seven women, were 21 to 57 years of age. The major hemodynamic abnormality in ten patients was mitral regurgitation; in one patient, mitral stenosis; in one patient, tricuspid regurgitation; and in two patients, combined aortic and mitral disease, necessitating replacement of both the aortic and mitral valves. Hemodynamic evaluation by right and left heart catheterization was carried out in all 14 patients who comprised this study. To represent nonfailing hearts, mitochondria also were prepared from right ventricular outflow tract muscle removed from two male patients with tetralogy of Fallot during correction of this congenital defect.

The general methods utilized in this clinic for mitral valve replacement have been previously described in detail (18). The preoperative medications were pentobarbital, atropine, and meperidine. Anesthesia was induced with thiopental and maintained with halothane in a concentration of 0.5 to $1.0 \%$. The mitral valve was exposed during total cardiopulmonary bypass, and after the valve leaflets had been detached from the anulus, the papillary muscles were divided from the ventricular wall at their origins and the valve and muscles removed en bloc. The patients' temperatures were usually $34^{\circ}$ to $35^{\circ} \mathrm{C}$, and bypass had been in progress for approximately 10 to 15 minutes when the papillary muscles were transected. Immediately upon removal of the specimen, it was placed on ice, dissected, and muscle tissue obtained that was free of fibrous connections to the valve.

Muscle specimens weighing 0.9 to $4.0 \mathrm{~g}$ were used for the isolation of mitochondria by a modification of the method of Hatefi, Jurtshuk, and Haavik (19). All tissues and materials were maintained at $0^{\circ} \mathrm{C}$. Tissue specimens were pressed through a stainless steel disc with $0.5-\mathrm{mm}$ perforations, and this tissue mince was suspended in 4 to 6 vol of $0.25 \mathrm{M}$ sucrose containing ATP, $\mathrm{MgCl}_{2}$, succinate, and Tris- $\mathrm{HCl}$ ( $\mathrm{pH} 7.8$ ) each in a concentration of $10^{-3}$ mole per L. Nagarse proteinase ${ }^{1}$ was added to a concentration of $1 \mathrm{mg}$ per $\mathrm{ml}$ and the mixture incubated in an ice bath for 20 minutes and intermittently stirred with a magnetic stirring bar. The tissue mince was transferred to a smooth-walled homogenizing vessel and disrupted with a loose-fitting motor-driven Teflon pestle with 15 strokes. The homogenate was centrifuged in a refrigerated centrifuge at $1,000 \times g$ (mean force) for 10 minutes. The supernatant fluid was decanted and centrifuged again at $25,000 \times g$ for 10 minutes to obtain the mitochondrial pellet. This was washed with $0.25 \mathrm{M}$ sucrose, recentrifuged at $25,000 \times g$ for 10 minutes, and resuspended in sufficient $0.25 \mathrm{M}$ sucrose to make a suspension that contained approximately $10 \mathrm{mg}$ of mitochondrial protein per $\mathrm{ml}(20)$. Mitochondria also were prepared from adult (700 to $900 \mathrm{~g}$ ) guinea pigs; left ventricles were pooled from two to three animals and treated in the same manner as the human tissues, except that incubation with Nagarse enzyme was for 10 minutes. Studies of mitochondrial function were done immediately.

Oxidative phosphorylation was studied by techniques similar to those described previously (21). Each flask

1 Obtained from Biddle Sawyer Corp., New York, N. Y. contained the following in a final volume of $1.0 \mathrm{ml}$ : glycylglycine buffer ( $\mathrm{pH} 7.4), 40 \mu$ moles; potassium phosphate ( $\mathrm{pH} 7.4$ ), $30 \mu$ moles; DPN, $1 \mu$ mole; cytochrome c, $0.015 \mu$ mole; $\mathrm{MgCl}_{2}, 5$ umoles; glucose, 25 $\mu$ moles; hexokinase (Sigma type III), $0.25 \mathrm{mg}$; and mitochondria, $0.25 \mathrm{ml}$. Incubation was for 20 minutes at $30^{\circ} \mathrm{C}$. Oxidative rates were determined manometrically, and the net uptake of phosphate was calculated from the differences between initial and final phosphate concentrations (22). All incubations were done in duplicate and the average values reported. Determinations of oxygen consumption were also carried out with the Clark electrode (23). Mitochondria $(0.2 \mathrm{ml})$ were incubated at $24^{\circ} \mathrm{C}$ in a sealed cuvette containing $1.5 \mathrm{ml}$ of the following: glycylglycine buffer ( $\mathrm{pH} 7.4), 30 \mu$ moles; potassium phosphate ( $\mathrm{pH} 7.4$ ), $5 \mu$ moles; $\mathrm{KCl}, 180 \mu$ moles; $\mathrm{MgCl}_{2}, 12 \mu$ moles; and substrate, $10 \mu$ moles. Additions to this medium are indicated in the Figures. Respiratory control ratios were determined manometrically and polarographically by dividing the oxidative rates in the presence of ADP acceptor by the rate measure when the ADP acceptor was absent (24). ATPase activity was assayed (21) in a medium containing $40 \mu$ moles glycyl-

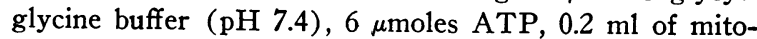
chondria, and sufficient $0.25 \mathrm{M}$ sucrose to make a final volume of $1 \mathrm{ml}$; additions are as indicated in Table III. Incubations were carried out at $30^{\circ} \mathrm{C}$ for 10 minutes.

Measurement of high energy phosphate compounds was made in biopsies of the myocardium taken from 14 patients with heart failure in whom replacement of the mitral or aortic valve or both was performed. In all patients rheumatic heart disease was responsible for the valvular deformity, and all were on maintenance digoxin. The patients were 21 to 53 years of age; nine were males and five females. The major hemodynamic abnormality in six patients was mitral regurgitation; in one patient, aortic regurgitation; in one patient, mitral stenosis; in six patients, aortic stenosis; and in one patient aortic stenosis was combined with mitral valve disease, necessitating replacement of both valves. For comparison, biopsies also were taken at the time of cardiac operation from eight patients without previous histories of heart failure who were undergoing repair of septal defects or pulmonic stenosis. Biopsies were taken from the right ventricle in the nonfailure group and from the left ventricle in the failure group 2 to 10 minutes after the institution of total cardiopulmonary bypass. In all patients body temperatures were $34^{\circ}$ to $35^{\circ} \mathrm{C}$, and the coronary circulation was intact.

Approximately $100 \mathrm{mg}$ of tissue was removed rapidly with a rongeur and immersed in liquid nitrogen within 3 seconds. Rapid removal and freezing of muscle tissue are essential because of the extreme lability of creatine phosphate in such tissue. Tissue was not frozen in situ by the technique of Wollenberger, Krause, and Wahler (25) because of the potential hazard to the patient. This biopsy method for measurement of high energy phosphate compounds was first evaluated in six openchest, adult, mongrel dogs anesthetized with Nembutal (35 $\mathrm{mg}$ per $\mathrm{kg}$ ). 
TABLE I

Anatomic and hemodynamic data of patients with heart failure from whom cardiac mitochondria were isolated and myocardial biopsies taken

\begin{tabular}{|c|c|c|c|c|c|c|c|c|c|c|}
\hline Patient & $\begin{array}{l}\text { Mito- } \\
\text { chon- } \\
\text { drial } \\
\text { studies }\end{array}$ & $\begin{array}{c}\text { Myo- } \\
\text { car- } \\
\text { dial } \\
\text { biopsy }\end{array}$ & Age & Diagnosis* & Operation $\dagger$ & Rhythm $\ddagger$ & $\begin{array}{c}\text { Cardiac } \\
\text { index }\end{array}$ & $\begin{array}{c}\text { Pulmo- } \\
\text { nary } \\
\text { arterial } \\
\text { pressure }\end{array}$ & $\begin{array}{l}\text { Left } \\
\text { atrial } \\
\text { mean } \\
\text { pres- } \\
\text { sure }\end{array}$ & $\begin{array}{l}\text { Left } \\
\text { ventric- } \\
\text { ular } \\
\text { pressure }\end{array}$ \\
\hline & & & years & & & & $L / m^{2}$ & $m m H g$ & $m m \mathrm{Hg}$ & $m m H g$ \\
\hline C.M. & + & + & 21 & MI, TI & MV & AF & 2.13 & $70 / 30$ & 18 & $100 / 10$ \\
\hline E.R. & + & + & 44 & MS, MI, TI & MV & $\mathrm{AF}$ & 1.78 & $55 / 30$ & 20 & $90 / 13$ \\
\hline A.F. & + & + & 48 & MI & MV & NSR & 1.80 & $84 / 30$ & 25 & $88 / 20$ \\
\hline M.W. & + & + & 21 & MI & MV & $\mathrm{AF}$ & 1.89 & $67 / 41$ & 22 & $110 / 15$ \\
\hline H.K. & + & + & 43 & MI, MS, TI & MV & $\mathrm{AF}$ & 1.55 & $70 / 40$ & & $100 / 8$ \\
\hline V.M. & + & + & 26 & MI, TS, TI & MV & AF & 1.77 & $65 / 32$ & 21 & $116 / 20$ \\
\hline C.J. $\S$ & + & & 49 & MI, MS, AI, AS & $\mathrm{MV}, \mathrm{AV}$ & $\mathrm{AF}$ & 2.27 & $36 / 16$ & & $138 / 3$ \\
\hline M.P. & + & & 50 & AS, AI, MS & $\mathrm{MV}, \mathrm{AV}$ & AF & 1.60 & $95 / 49$ & 23 & $151 / 5$ \\
\hline A.V. & + & & 36 & MI & MV & AF & 2.16 & $32 / 15$ & 15 & $115 / 7$ \\
\hline L.S. & + & & 17 & MI & MV & NSR & & $72 / 42$ & & $86 / 12$ \\
\hline M.V. & + & & 57 & TI, MS & TV & AF & 3.08 & $52 / 15$ & 19 & $118 / 12$ \\
\hline T.E. & + & & 49 & MI, MS & MV & AF & 2.21 & $38 / 15$ & 23 & $138 / 12$ \\
\hline R.F. & + & & 50 & MI, MS, AI & MV & AF & 1.66 & $70 / 30$ & 25 & $135 / 6$ \\
\hline P.R. & + & & 24 & MI & MV & AF & 1.63 & $40 / 20$ & 16 & $130 / 5$ \\
\hline T.L. & & + & 45 & AS, AI, MS, TS & AV & $\mathrm{AF}$ & 2.44 & $28 / 16$ & 12 & $142 / 5$ \\
\hline A.C. & & + & 53 & AS & AV & NSR & 2.81 & $36 / 18$ & 29 & $121 / 36$ \\
\hline A. $K$. & & + & 52 & AS & AV & NSR & 2.43 & $23 / 11$ & & $110 / 7$ \\
\hline L.M. & & + & 24 & AS, AI, MS, MI & MV, AV & NSR & 1.74 & $90 / 40$ & 27 & $128 / 13$ \\
\hline L.R. & & + & 35 & $\mathrm{AS}, \mathrm{AI}$ & AV & NSR & 2.14 & $40 / 20$ & 15 & $134 / 30$ \\
\hline E.D. & & + & 42 & AI & AV & NSR & 1.82 & $45 / 25$ & & $155 / 15$ \\
\hline E.R. & & + & 44 & AS & AV & NSR & 2.81 & $28 / 15$ & 11 & $108 / 22$ \\
\hline D.L. & & + & 61 & MI, TI & MV & $\mathbf{A F}$ & & $60 / 25$ & 22 & $102 / 15$ \\
\hline
\end{tabular}

* MS = mitral stenosis; $\mathrm{MI}=$ mitral regurgitation; $\mathrm{TS}=$ tricuspid stenosis; $\mathrm{TI}=$ tricuspid regurgitation; AS = aortic stenosis, and $\mathrm{AI}$ $=$ aortic regurgitation.

t $\mathrm{MV}=$ mitral valve; $\mathrm{AV}=$ aortic valve; $\mathrm{TV}=$ tricuspid valve.

AF $=$ atrial fibrillation; NSR $=$ normal sinus rhythm.
Hemodynamic data obtained 2 years before operation.

The frozen tissue was weighed, pulverized with 10 vol of frozen $0.3 \mathrm{M}$ perchloric acid in a Nossal disintegrator ${ }^{2}$ at $-20^{\circ} \mathrm{C}$, and the frozen powder gradually thawed while mixing. Inorganic and creatine phosphate were determined by the method of Furchgott and De Gubareff (26). The ATP content of the tissue extract was measured with a preparation of firefly lantern. Light emitted from a $1.2 \mathrm{ml}$-reaction mixture containing $5 \mathrm{mg}$ of lantern extract, $^{3} 5$ momoles perchloric acid, and 0.1 to $3.0 \mathrm{~m} \mu$ moles ATP was measured with an Aminco photomultiplier.

Tissues for examination with the electron microscope were removed during cardiac operations in four patients with failure (A.F., C.J., V.M., and M.P.) and in three patients with atrial and ventricular septal defects and no history of failure. Specimens were immediately stretched and mounted on hard rubber at a minimal tension and fixed in osmium tetraoxide buffered to $\mathrm{pH} 7.4$ with phosphate (27). The specimens were dehydrated in alcohol, embedded in Epon, sectioned, and examined in an RCA (model EMU-3G) electron microscope.

\section{Results}

Hemodynamic data. The 22 patients from whom either papillary muscles were removed for

${ }^{2}$ McDonald Equipment Co., Cleveland, Ohio.

${ }^{3}$ Sigma Chemical Co., St. Louis, Mo. mitochondrial studies or biopsies were taken for determination of high energy phosphate compounds, and whose hemodynamic status is presented in Table I, all had symptoms of markedly reduced cardiac reserve and were in functional classes III or IV. Atrial fibrillation was present in 14. The cardiac index was $2.4 \mathrm{~L}$ per minute per $\mathrm{m}^{2}$, the lower limit of normal, or less in all but three patients, and in ten patients it was markedly reduced to below $2.0 \mathrm{~L}$ per minute per $\mathrm{m}^{2}$. Severe pulmonary hypertension, indicated by a pulmonary arterial systolic pressure greater than 50 $\mathrm{mm} \mathrm{Hg}$, was present in 12 of the patients, and the mean left atrial pressure exceeded $12 \mathrm{~mm} \mathrm{Hg}$ in all but two of the 17 patients in whom this measurement was made. The left ventricular enddiastolic pressure was $12 \mathrm{~mm} \mathrm{Hg}$ or greater in 13 patients. One patient (C.J.) was too ill to be studied immediately before operation, and the data reported are those obtained at catheterization 2 years earlier. The mitral valve alone was replaced in 12 , both the mitral and aortic in three, the aortic valve alone in six, and the tricuspid alone 
in one. The two patients with tetralogy of Fallot had pronounced right ventricular hypertension but no evidence of heart failure.

Mitochondrial function. The manometric studies conducted with mitochondria derived from the 11 patients with rheumatic heart disease demonstrated a normal capacity for oxidative phosphorylation (Table II). The yield of mitochondria averaged $9.2 \mathrm{mg}$ of mitochondrial protein per $\mathrm{g}$ of tissue. The oxidative rate averaged 4.1 $\mu$ Atoms $\mathrm{O}$ per $\mathrm{mg}$ mitochondrial protein per 20 minutes with pyruvate and malate as substrates and was substantially less, $2.0 \mu$ Atoms $O$ per mg per 20 minutes, with succinate. The ratios of phosphate utilization to the oxygen consumption ( $\mathrm{P} / \mathrm{O}$ ratio) closely approximated the expected normal values of 3 for pyruvate-malate and 2 for succinate, averaging, respectively, 2.8 and 2.2. In five preparations, respiratory control ratios with pyruvate and malate averaged 7.9 and in all cases were in excess of 4.0. Similar results also were obtained with mitochondria derived from the two patients with tetralogy of Fallot. The values with human heart mitochondria are compared to those obtained with mitochondria from normal guinea pig hearts (Table II). The data are similar except that the oxidative rates were somewhat less with the preparations from the experimental animal. The rate of oxidation with succinate was less than with pyruvate-malate, and respiratory control with succinate was absent when measured manometrically in both the guinea pig and human mitochondria.

Polarographic measurement of oxidative phosphorylation in mitochondrial preparations obtained from three patients (L.S., R.F., and P.R.) also revealed that coupling between electron transport and phosphorylation was preserved in the iso-

TABLE II

Oxidative phosphorylation determined manometrically in mitochondria isolated from the failing human myocardium

\begin{tabular}{|c|c|c|c|c|}
\hline Substrate & $\begin{array}{l}\text { Mitochon- } \\
\text { drial yield }\end{array}$ & Qo2* & P/O† & $\begin{array}{c}\text { Respiratory } \\
\text { control ratiof }\end{array}$ \\
\hline & $\begin{array}{c}\text { mg protein/ } \\
\text { g muscle }\end{array}$ & $\underset{20 \text { min }}{\mu \text { Atoms } O / \mathrm{mg} /}$ & & \\
\hline $\begin{array}{cc}\text { Rheumatic heart disease } \\
\text { E.R. } & \text { Pyruvate-malate } \\
\text { C.M. } & \text { Pyruvate-malate } \\
\text { A.F. } & \text { Pyruvate-malate } \\
\text { C.S. } & \text { Pyruvate-malate } \\
\text { M.W. } & \text { Pyruvate-malate } \\
\text { H.K. } & \text { Pyruvate-malate } \\
\text { A.V. } & \text { Pyruvate-malate } \\
\text { V.M. } & \text { Pyruvate-malate } \\
\text { L.S. } & \text { Pyruvate-malate }\end{array}$ & $\begin{array}{r}8.2 \\
7.6 \\
8.6 \\
11.0 \\
11.9 \\
5.7 \\
10.0 \\
9.6 \\
9.1\end{array}$ & $\begin{array}{l}3.6 \\
3.6 \\
5.8 \\
3.8 \\
4.1 \\
5.3 \\
4.7 \\
2.8 \\
3.0\end{array}$ & $\begin{array}{l}2.2 \\
3.1 \\
2.7 \\
2.6 \\
2.6 \\
3.3 \\
2.3 \\
3.5 \\
3.0\end{array}$ & $\begin{array}{r}9.0 \\
4.4 \\
10.0 \\
5.2 \\
11.1\end{array}$ \\
\hline Mean & 9.1 & 4.1 & 2.8 & 7.9 \\
\hline $\begin{array}{l}\text { Succinate } \\
\text { Succinate } \\
\text { Succinate }\end{array}$ & $\begin{array}{r}8.0 \\
10.0 \\
11.9\end{array}$ & $\begin{array}{l}1.9 \\
1.5 \\
2.6\end{array}$ & $\begin{array}{l}2.2 \\
2.3 \\
2.0\end{array}$ & 1.0 \\
\hline Mean & 10.0 & 2.0 & 2.2 & 1.0 \\
\hline $\begin{array}{cc}\text { Tetralogy of Fallot } \\
\text { J.B. } & \text { Pyruvate-malate } \\
\text { L.G. } & \text { Pyruvate-malate }\end{array}$ & $\begin{array}{r}8.8 \\
10.0\end{array}$ & $\begin{array}{l}3.4 \\
3.0\end{array}$ & $\begin{array}{l}2.7 \\
2.5\end{array}$ & $\begin{array}{r}5.7 \\
20.0\end{array}$ \\
\hline Mean & 9.4 & 3.2 & 2.6 & 12.9 \\
\hline $\begin{array}{c}\text { Guinea pig mitochondria } \S \\
\text { Pyruvate-malate } \\
\text { Succinate }\end{array}$ & $\begin{array}{l}5.4 \\
5.4\end{array}$ & $\begin{array}{l}2.4 \\
(1.3-3.4) \\
1.5 \\
(1.5-3.4)\end{array}$ & $\begin{array}{l}2.9 \\
(2.6-3.1) \\
2.0 \\
(1.8-2.1)\end{array}$ & $\begin{array}{c}8 \\
(4.0-12.0) \\
0.9 \\
(0.8-1.0)\end{array}$ \\
\hline
\end{tabular}

\footnotetext{
${ }^{*} \mathrm{Q}_{\mathrm{O} 2}=$ oxygen consumption.

$\dagger \mathrm{P} / \mathrm{O}=$ ratio of phosphate utilized to oxygen consumed.

$\ddagger$ Respiratory control ratio = rate of oxidation with added phosphate acceptor (ADP, hexokinase, and glucose) divided by rate of oxidation without acceptor.

\$ These values are the mean of three preparations with each substrate.
} 


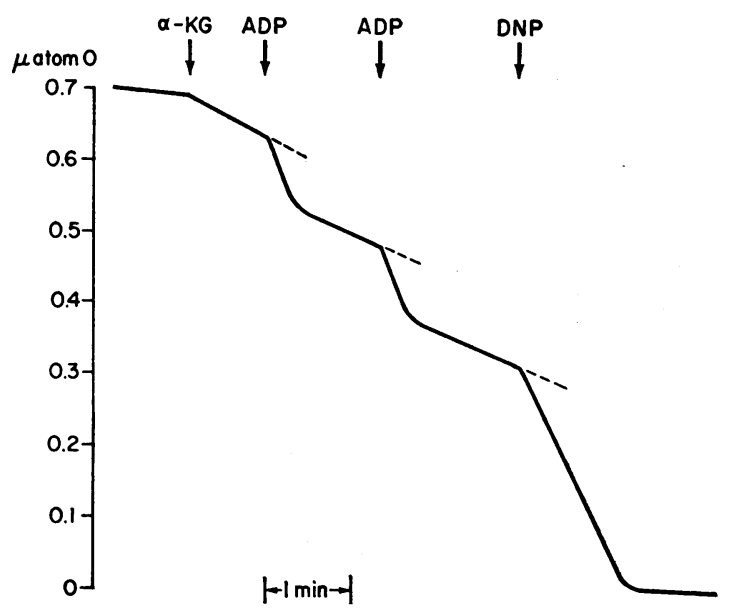

Fig. 1. A REPRESENTATIVE POLAROGRAPHIC TRACING OBTAINED WITH MITOCHONDRIA PREPARED FROM LEFT VENTRICULAR PAPILLARY MUSCLES OF A PATIENT WITH HEART FAILURE (R.F.). The tracing, indicating the amount of oxygen in the incubation mixture, begins upon the addition of mitochondria. Initial respiration is minimal and increases upon addition of substrate, $\alpha$-ketoglutarate $(\alpha-K G)$. The additions of ADP demonstrate the respiratory control of the mitochondrial preparation: the rate of maximal respiration in the presence of $\mathrm{ADP} /$ rate of respiration when no ADP is present. The respiratory control ratio is 6.3 , and the $\mathrm{P} / \mathrm{O}$ ratio, calculated from these data (24), is 2.9. Stimulation of respiration is temporary with ADP lasting until the added nucleotide is consumed, whereas after the addition of the uncoupling reagent, 2,4-dinitrophenol (DNP), maximal respiration occurs until all the oxygen has been reduced in the system. (For details of reaction mixture see Methods.)

lated mitochondria (Figures 1 and 2). $\mathrm{P} / \mathrm{O}$ ratios (ADP utilization/oxygen consumption) averaged 3.3 (3.0 to 3.6) with pyruvate-malate, 2.2 (2.0 to 2.4 ) with succinate, and 3.1 ( 2.8 to 3.5 )

TABLE III

ATPase activity of mitochondria isolated from the failing human myocardium

\begin{tabular}{|c|c|c|c|c|}
\hline Patient & $\begin{array}{l}\text { Endog- } \\
\text { enous }\end{array}$ & $\mathrm{Mg}^{++*}$ & DNP* & $\begin{array}{l}\text { Oligo- } \\
\text { mycin* }\end{array}$ \\
\hline & \multicolumn{4}{|c|}{$\begin{array}{l}\mu \text { moles } \mathrm{PO}_{4} \text { liberated } / \mathrm{mg} \text { mito- } \\
\text { chondrial protein } / 10 \mathrm{~min}\end{array}$} \\
\hline $\begin{array}{l}\text { C.M. } \\
\text { C.J. } \\
\text { M.W. } \\
\text { H.K. } \\
\text { A.V. } \\
\text { T.K. } \\
\text { R.F. } \\
\text { P.R. }\end{array}$ & $\begin{array}{l}0.34 \\
0.16 \\
0.13 \\
0.29 \\
0.45 \\
0.30 \\
0.00 \\
0.14\end{array}$ & $\begin{array}{l}0.72 \\
0.61 \\
0.24 \\
0.85 \\
0.90 \\
0.80 \\
0.10 \\
0.50\end{array}$ & $\begin{array}{l}2.50 \\
2.72 \\
3.94 \\
2.84 \\
2.50 \\
2.72 \\
2.42\end{array}$ & $\begin{array}{l}0.14 \\
0.00 \\
0.29\end{array}$ \\
\hline Average & 0.22 & 0.59 & 2.80 & 0.14 \\
\hline J.B.† & 0.50 & 0.96 & 2.70 & 0.37 \\
\hline
\end{tabular}

$* \mathrm{Mg}^{++}=\mathrm{MgCl}_{2}, 5 \mu$ moles added to each tube; DNP $=2,4$-dinitrophenol, $0.1 \mu$ mole added to each tube; oligomycin, $5 \mu \mathrm{g}$ added to each tube with DNP.

$\uparrow$ Patient with tetralogy of Fallot; all other patients had rheumatic heart disease. with $\alpha$-ketoglutarate. Respiratory control ratios averaged 5.6 (4.4 to 7.0 ) with pyruvate-malate, 3.9 (3.8 to 3.9 ) with succinate, and 5.6 (4.9 to 6.3) with $\alpha$-ketoglutarate. In these incubations (less than 5 minutes) significant respiratory control could be demonstrated with succinate as the substrate, whereas it was not present in the longer manometric incubations. In each study, uncoupling by 2,4-dinitrophenol released respiratory control (Figures 1 and 2), and maximal rates of oxidation, comparable to those obtained with ADP, were achieved.

ATPase activity was determined in mitochondria isolated from the muscles of eight patients with rheumatic heart disease and from one patient with tetralogy of Fallot (Table III). The endogenous activity averaged $0.22 \mu$ mole of phosphate liberated per $\mathrm{mg}$ of mitochondrial protein per 10 minutes. This activity increased to 0.59 in the presence of magnesium ion. A pronounced increase in activity was observed in the presence of 2,4-dinitrophenol. This augmented activity was completely inhibited in the presence of oligomycin. Since oligomycin is a specific inhibitor of mitochondrial ATPase activated by 2,4-dinitrophenol (28), this response is evidence that the enzyme activity that has been determined is truly of mitochondrial origin and not due to contamination by

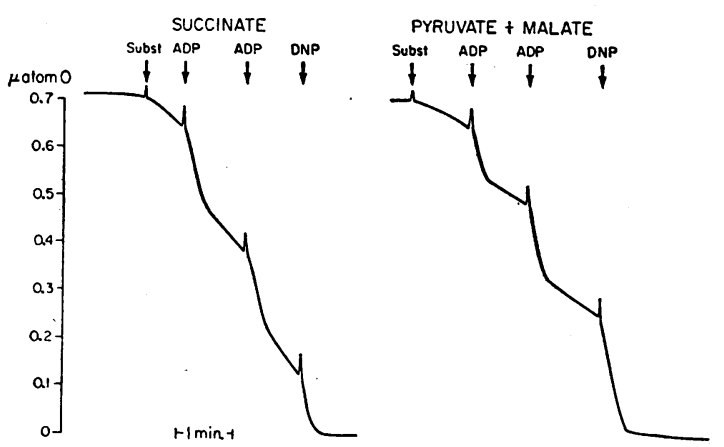

Fig. 2. Two Representative polarographic tracings OBTAINED WITH MITOCHONDRIA PREPARED FROM LEFT VENTRICULAR PAPILLARY MUSCLES OF A PATIENT WITH HEART FAILURE (P.R.). The details are the same as those described in Figure 1 except that the substrates used are succinate (left) and pyruvate/malate (right). Respiratory control ratios are 3.9 with succinate and 7.0 with pyruvate/malate, and the $\mathrm{P} / \mathrm{O}$ ratios, calculated from these data, are 2.3 and 3.3 , respectively. The effect of uncoupling oxidative phosphorylation is demonstrated after the addition of DNP where maximal respiration occurs until all the oxygen has been reduced. 


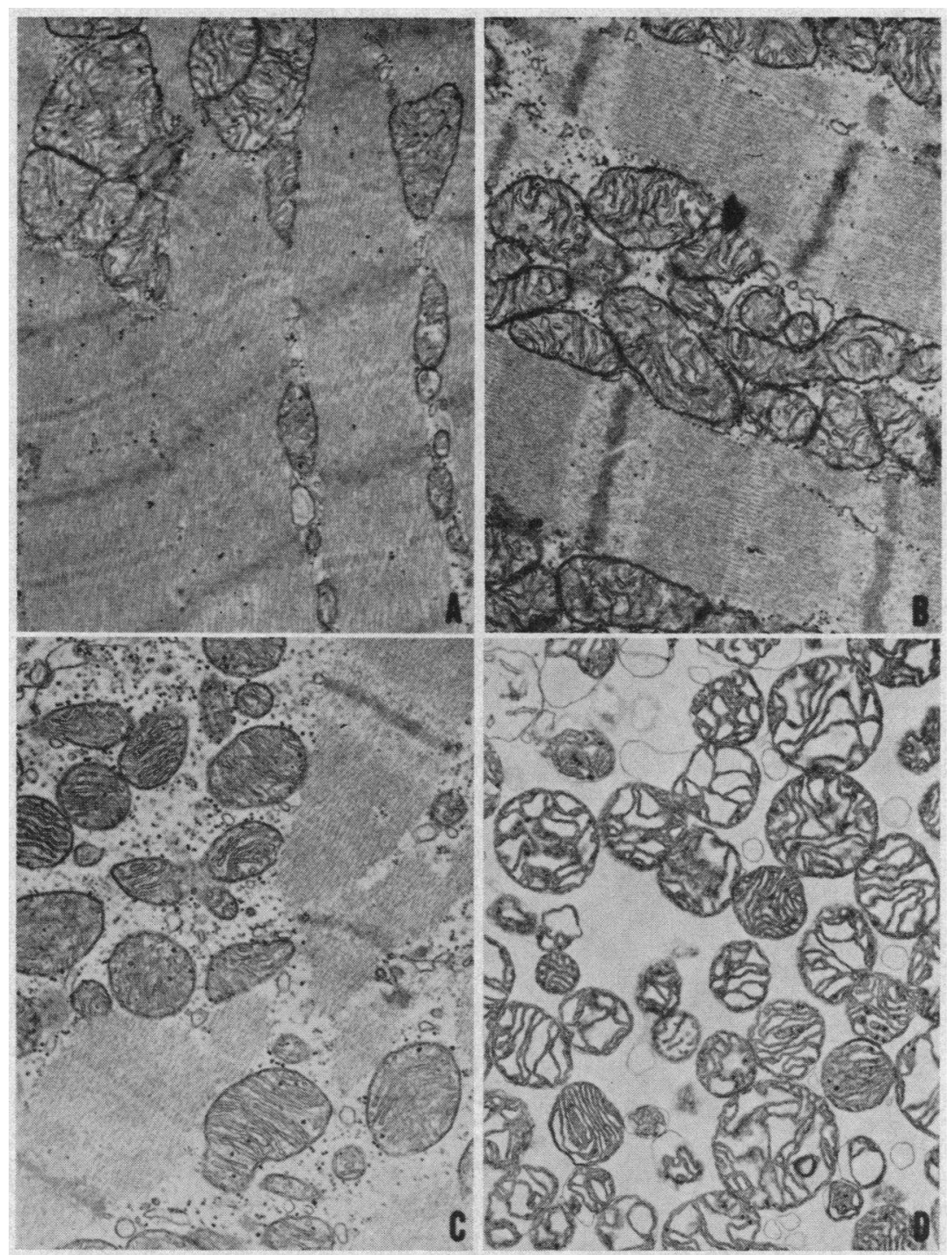

Fig. 3. EleCtron MiCROGRAPHS OF VENTRICULAR MYOCARDIUM REMOVEd FROM PATIENTS DURING CARDIAC SURGERY $(\times 20,900)$. A $)$ Right ventricular tissue removed from a 20-year-old patient with a ventricular septal defect. The mitochondria, lying between myofibrils, exhibit profiles ranging from 250 to $1,250 \mathrm{~m} \mu$. The interior of the mitochondria is filled with densely packed cristae. $B$ ) Left ventricular tissue removed from a patient with severe heart failure (C.J., Table I). Mitochondria in the same range of size as those in $A$ are present. The cristae filling the organelle appear to be comparable to those seen in mitochondria of the nonfailing heart. Myofibrils are shown in longitudinal section, and the typical sarcomere pattern (29) is present without visable derangement. $C$ ) and $D$ ) Mitochondria in left ventricular tissue removed from a patient with severe heart failure (M.P., Table I). The mitochondria are shown in situ, $C$, and in vitro after isolation, $D$. Some swelling of the organelle has occurred as a result of the isolation, but this swelling is minimal. No structures of nonmitochondrial origin are visible.

other cellular constituents. In a single experiment using mitochondria prepared from the right ventricular tissue removed from one of the pa- tients with tetralogy of Fallot (J.B.), comparable values were obtained.

Mitochondrial morphology. Examination of the 
fine structure of mitochondria in tissues removed from patients with heart failure did not disclose any structural alterations when compared to mitochondria in tissues obtained from patients without heart failure (Figure 3). The over-all size of the organelle in situ was not increased in the failing heart, and the structure of the cristae as well as that of the matrix did not exhibit any apparent abnormality. Furthermore, examination of these mitochondria even after isolation revealed no aberrations in the mitochondrial profiles, although there was some swelling that is commonly seen in all isolated preparations. No attempt was made to quantify with precision the mitochondrial concentration in the sarcoplasm, but no gross increase in the number of mitochondria was apparent when the morphology of the failing myocardium was compared to that of the nonfailing tissue.

Myocardial high energy phosphate. By the biopsy method for determination of high energy phosphate compounds in the canine myocardium, the concentration of creatine phosphate averaged $13.3 \pm 0.30$ ( $\mathrm{SE}$ of the mean) $\mu$ moles per $\mathrm{g}$ in the right and $12.9 \pm 0.59 \mu$ moles per $g$ in the left ventricle $(\mathrm{p}>0.10)$. ATP concentrations, measured only in the left ventricle, averaged $4.6 \pm 0.2$ $\mu$ moles per $g$. In the patients the concentrations
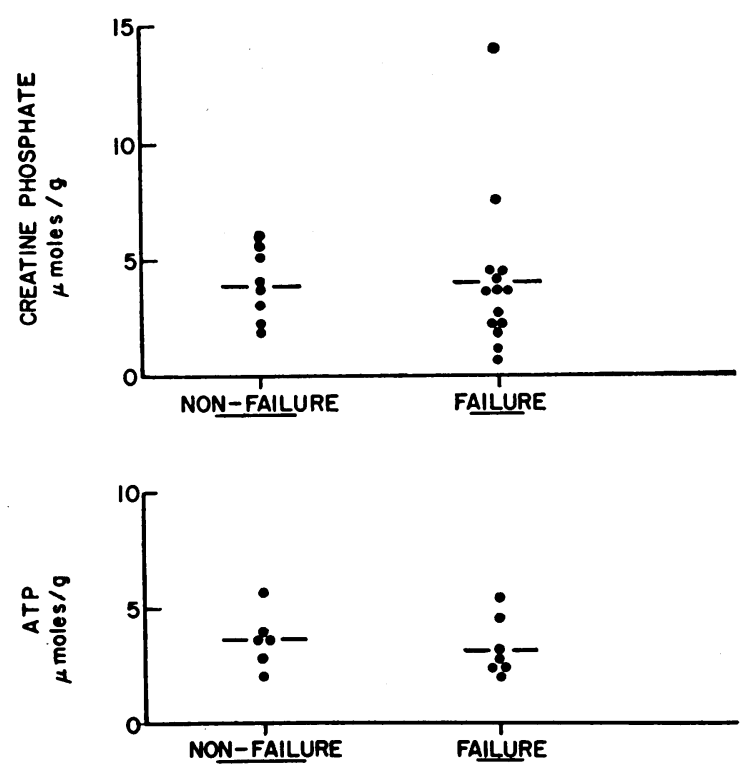

Fig. 4. Concentration of CReatine phosphate and ATP IN VENTRICULAR BIOPSIES REMOVED FROM PATIENTS WITH AND WITHOUT HISTORIES OF HEART FAILURE. The individual concentrations are shown and the mean values indicated. of both compounds were lower than in the dogs. The concentrations of creatine phosphate were essentially the same in myocardial biopsies taken from eight patients without cardiac decompensation and 14 patients with congestive failure, averaging $3.9 \pm 0.5$ and $4.0 \pm 0.9 \mu$ moles per g, respectively (Figure 4). The inorganic phosphate concentrations, which are not presented in the Figure, averaged $4.2 \pm 0.4$ (2.6 to 5.6) $\mu$ moles per $\mathrm{g}$ in the nonfailure group and $3.6 \pm 0.4$ (1.7 to 7.6) $\mu$ moles per $g$ in the failure group. The difference in these values was not significant $(p>$ $0.10)$. The ATP concentrations determined in six patients without cardiac decompensation averaged 3.6 $\pm 0.6 \mu$ moles per $\mathrm{g}$ and were not significantly diminished in seven patients with congestive failure averaging $3.2 \pm 0.5 \mu$ moles per $g$ ( $p>$ $0.10)$.

\section{Discussion}

Previous studies of energy production in clinical heart failure have been limited to an evaluation of the myocardial utilization of substrates and oxygen, based on measurements of arteriovenous differences and coronary blood flow (1-3). Although this approach demonstrated that substrate and oxygen utilization per $100 \mathrm{~g}$ of myocardium was normal at rest in patients with congestive heart failure, and increased appropriately during exercise, there are certain definite limitations of these methods that must be emphasized. First, the exchange of substrate and oxygen at the level of the vascular bed does not necessarily indicate the extent to which this potential chemical energy becomes available for useful cellular work, and this can be answered only by demonstrating that the conversion of substrate energy to high energy phosphate compounds within the cell is normal. Any such defect in oxidative phosphorylation would result in subnormal energy production even in the presence of normal or increased oxygen and substrate utilization. Furthermore, the use of the inert gas method to measure total coronary blood flow may not be entirely valid, particularly when nonhomogeneous perfusion and nonsteady states pertain $(30,31)$. Thus, it is possible that abnormalities of energy metabolism might exist in the failing heart and remain undetected by studies of coronary sinus catheterization (32).

The mitochondrion is the intracellular structure 
in which the chemical energy contained within substrates is converted into a form available for cellular utilization. By means of oxidative phosphorylation, a part of the free energy released during the transport of electrons from substrate to oxygen is retained in high energy intermediates that ultimately result in the formation of ATP (33). Studies have been carried out with mitochondria isolated from the ventricles of experimental animals in heart failure to determine whether there was an abnormality of oxidative phosphorylation, and conflicting results have been obtained. In acutely failing ventricles, oxidative phosphorylation was found to be normal in some studies (10) and depressed in others (34). Similarly, no agreement has been reached regarding oxidative phosphorylation in chronically failing experimental preparations. There have been reports that right heart failure in the dog, produced by tricuspid insufficiency and pulmonary stenosis, does not interfere with mitochondrial function (17). However, a detailed investigation in the guinea pig has shown that chronic left ventricular failure is accompanied by an alteration of oxidative phosphorylation manifested by a reduction of $\mathrm{P} / \mathrm{O}$ and of respiratory control ratios (11). Also, studies of mitochondria isolated from the hypertrophied but nonfailing canine left ventricle have demonstrated abnormal oxidative phosphorylation (35). Diminished myocardial concentrations of the mitochondrial enzyme, malic dehydrogenase, also have been found in the hypertrophied canine ventricle (35). Similar reductions of this and other mitochondrial enzymes were reported in postmortem specimens obtained from patients with heart failure (32).

We have attempted to evaluate mitochondrial function in the human heart using tissue obtained from left ventricular papillary muscles removed at the time of mitral valve replacement (18). This tissue has provided the only opportunity to measure in vitro the functional capacity of mitochondria from the viable human heart, as opposed to study of postmortem tissue where variable degrees of autolysis may be present. The results indicate that, in vitro, electron transport is tightly coupled to phosphorylation in the mitochondria prepared from ventricular tissue removed from patients who clearly exhibited hemodynamic evidence of heart failure (Table I). Thus, $\mathrm{P} / \mathrm{O}$ ra- tios closely approximated the expected normal values with pyruvate-malate or succinate as substrate. The more sensitive index of coupled phosphorylation, the respiratory control ratio (24), has also confirmed the functional integrity of these organelles (Figures 1 and 2). Furthermore, these findings have been supported by measurements of mitochondrial ATPase activities, which have indicated that the endogenous enzyme activity of the mitochondria can be augmented greatly by 2,4-dinitrophenol, a reagent that uncouples oxidative phosphorylation. The 15-fold increase in ATPase with 2,4-dinitrophenol demonstrates that, even after isolation of the mitochondria, only minimal functional derangement could be present, since no such augmentation would occur in damaged mitochondria (33). The measurements of oxidative phosphorylation in two patients with tetralogy of Fallot, and of ATPase activity in one of these, provide further control observations of mitochondria from nonfailing hearts for comparison with the studies carried out with mitochondria from failing hearts. The results of these measurements were similar in both groups of patients. However, it should be recognized that these mitochondria were assayed in a fortified medium in which optimal concentrations of substrates, cofactors, and oxygen were present. It is still possible that in situ the cardiac mitochondria are not so richly endowed.

Since morphologic changes of the mitochondria also have been described in the hypertrophied but nonfailing canine ventricle (36) and in the failing rabbit ventricle after aortic constriction (15), attention also was directed to the structural characteristics of mitochondria examined in biopsies of these failing human hearts (Figure 3 ). When these mitochondria were compared with mitochondria examined in nonfailing hearts, no gross abnormality of their structure or number was noted. Biopsies from only four patients with heart failure were studied, and it may be questioned whether these observations are representative of the most advanced ventricular failure. However, the hemodynamic data in three of these patients indicated marked left ventricular failure with cardiac indexes 1.8 per $\mathrm{L}$ minute per $\mathrm{m}^{2}$ or below, pulmonary arterial systolic pressure of 65 $\mathrm{mm} \mathrm{Hg}$ or more, and elevated left ventricular end diastolic pressure in two of three patients. The 
fourth patient (C.J.) was too ill to be studied before operation and required replacement of both the aortic and mitral valves. A specific effort was not directed toward an evaluation of sarcomere structure, but no gross derangement of this basic contractile unit (29) was noted in the sections of failing myocardium that were examined (Figure $3)$. Specifically, there was no increase of the central $\mathrm{H}$-zone as described in acutely dilated canine hearts (37). It must be emphasized in this regard, however, that it was not possible to fix the tissues at either tensions or muscle lengths necessarily corresponding to those present in vivo, and such a method of fixation would be required to evaluate this point critically.

The amount of energy available to the contractile apparatus also has been studied in heart failure in the experimental animal. Again, the results have been conflicting, with some reports indicating depressed concentrations of creatine phosphate and $\operatorname{ATP}(12,13,38,39)$ and others no change $(9,17)$. The determination of creatine phosphate is difficult because of its extreme lability in tissue biopsies (25). Thus, many studies in which this phosphate compound has been measured were complicated by substantial hydrolysis of the material before the specimen was frozen. The method employed in the present study for determination of creatine phosphate in the human heart was first used in the dog. With this method values were obtained that were comparable to the highest reported myocardial creatine phosphate concentrations (25); no consistent difference was encountered in the concentrations determined in the right and left ventricles. Therefore, we believe that the creatine phosphate and ATP concentrations reported in these studies of the human heart are based on valid methods and that the comparison between the biopsies of the right ventricle in the patients without heart failure and those of the left ventricle in the patients with failure are justified. A wide range of values, which may be the result of the variability of local myocardial perfusion in the biopsied tissue, was encountered in both groups of patients. Although no reduction of the content of high energy phosphate compounds was detected in these patients, it must be emphasized that a small but functionally important reduction in either creatine phosphate or ATP might have been present but not observed because of the range of varia- tion encountered in these observations. The low level of creatine phosphate observed in both groups of patients, especially when compared to the ATP concentration, is notable. Although equal amounts of creatine phosphate and ATP were found in these human biopsies, in the dog the concentration of creatine phosphate is approximately three times that of ATP.

Thus, oxidative phosphorylation, when studied under optimal in vitro conditions, was normal in mitochondria obtained from the failing human heart, and a significant reduction in the myocardial content of high energy phosphate compounds was not detected by methods employed in this study. Although there are certain limitations to the interpretation of these findings, which have been previously emphasized, it seems unlikely that an abnormality of energy production can be responsible for the defective myocardial performance in heart failure. Some consideration must be given to the differences in observations made in the present study and in previous studies in the experimental animal. It is possible that the severity of heart failure was greater in the experimental preparations and that, if mitochondria from patients with more advanced heart failure had been studied, an abnormality might have been detected. The hemodynamic burden of mitral regurgitation that was present in many of these patients may not be so stressful as the experimental lesions imposing outflow obstructions. Several patients with aortic stenosis were also studied, however, and an impairment of energy production was not detected by the methods used in this study. It may be questioned whether tissue from papillary muscles is representative of the mural ventricular contractile mass. Recently, a depression of the lengthtension relationship has been demonstrated in such muscles obtained from failing human hearts (40), and, therefore, it seems justifiable to consider these papillary tissues as representative of the failing heart. Also, digitalis therapy, which was present in all of these patients, may have had some influence on these measurements, although its acute administration was without effect on the abnormality of energy production in experimental failure (11). Finally, it is possible that the differences that have been encountered are due to the rate of development of ventricular failure. In the clinical setting, cardiac failure has a relatively slow 
onset, whereas, even in the chronic failure preparations in experimental animals, outflow obstruction is produced acutely. An explosive series of cellular adaptations occurs concomitant with the rapid development of ventricular hypertrophy (41), and it is entirely possible that these adaptations may result in disorders of mitochondrial structure and function. It is unlikely, however, that cardiac disease in man often requires such profound cellular compensations.

\section{Summary}

Observations in experimental animals have indicated that there may be a bioenergetic defect in the failing heart, characterized by an impairment of oxidative phosphorylation. In the present study, this question was examined in man, making use of myocardial tissues obtained from patients at the time of cardiac operations. Mitochondria were isolated from papillary muscles removed from the ventricle during replacement of the mitral and tricuspid valves in patients with chronic heart failure. Measurement of oxidative phosphorylation gave ratios of phosphate utilized to oxygen consumed averaging 2.8 with pyruvate/malate as substrate, and 2.2 with succinate. Respiratory control ratios, determined both manometrically and polarographically, averaged 7.1 with pyruvate/ malate, 5.6 with $\alpha$-ketoglutarate, and 3.9 with succinate. Average endogenous ATPase activity was $0.22 \mu$ mole phosphate liberated per. minute per $\mathrm{mg}$ mitochondrial protein; it rose to 0.59 with $\mathrm{Mg}^{++}$, to 2.80 with 2,4-dinitrophenol, and was completely inhibited by oligomycin. These values are comparable to those reported for normal mitochondria obtained from experimental animals. Examination of myocardial tissue by electron microscopy revealed no apparent mitochondrial abnormality. Creatine phosphate was determined in rapidly frozen ventricular biopsies in patients with heart failure undergoing valve replacement. The mean tissue concentration was $4.0 \mu$ moles per $\mathrm{g}$ compared to $3.9 \mu$ moles per $g$ in biopsies from patients without heart failure. Similarly, no significant reduction of ATP was found in the failing heart.

These observations have indicated that electron transport and coupled phosphorylation were normal in mitochondria isolated from failing human hearts when functional studies were carried out under optimal in vitro conditions, and that there was no detectable reduction of the content of high energy phosphate compounds in these hearts. Although there are certain limitations to the interpretation of these findings, it seems unlikely that energy production in the myocardium is necessarily impaired in patients with pronounced congestive heart failure. If a biochemical abnormality is responsible for the defective ventricular function in such patients, it would appear to involve the utilization of energy in the contractile process.

\section{Acknowledgments}

We are indebted to Dr. Harley G. Sheffield for the electron microscopy and to Mr. C. Elwood Claggett and Miss Kathleen Daly for technical assistance.

\section{References}

1. Bing, R. J., A. Siegel, A. Vitale, F. Balboni, E. Sparks, M. Taeschler, M. Klapper, and S. Edwards. Metabolic studies on the human heart in vivo. I. Studies on carbohydrate metabolism of the human heart. Amer. J. Med. 1953, 15, 284.

2. Blain, J. M., H. Schafer, A. L. Siegel, and R. J. Bing. Studies on myocardial metabolism: VI. Myocardial metabolism in congestive failure. Amer. J. Med. 1956, 20, 820.

3. Goodale, W. T., R. E. Olson, and D. B. Hackel. Myocardial glucose, lactate and pyruvate metabolism of normal and failing hearts studied by coronary venous catheterization in man. Fed. Proc. 1950, 9, 49.

4. Cain, D. F., and R. E. Davies. Brealkdown of adenosine triphosphate during a single contraction of working muscle. Biochem. biophys. Res. Commun. 1962, 8, 361.

5. Slater, E. C. . Uncouplers and inhibitors of oxidative phosphorylation in Metabolic Inhibitors, R. M. Hochster and J. H. Quastel, Eds. New York, Academic Press, 1963, vol. 2, p. 503.

6. Buffa, P., E. Carafoli, and V. Muscatello. Mitochondrial biochemical lesion and pyrogenic effect of pentachlorophenol. Biochem. Pharmacol. 1963, $12,769$.

7. Fonnesu, A. Changes in energy transformation as an early response to cell injury in The Biochemical Response to Injury, H. B. Stone and C. J. Threlfall, Eds. Oxford, England, Blackwell, 1960, p. 85.

8. Luft, R., D. Ikkos, G. Palmieri, L. Ernster, and B. Afzelius. A case of severe hypermetabolism of nonthyroid origin with a defect in the maintenance of mitochondrial respiratory control: a correlated clinical, biochemical, and morphological study. J. clin. Invest. 1962, 41, 1776.

9. Wollenberger, A. The energy metabolism of the failing heart and the metabolic action of the cardiac glycosides. Pharmacol. Rev. 1949, 1, 311.

10. Brody, T. M., J. F. Palmer, and D. R. Bennett. Phosphorylation in cardiac muscle from failing 
and unfailing heart-lung preparations. Proc. Soc. exp. Biol. (N. Y.) 1954, 86, 739.

11. Schwartz, A., and K. S. Lee. Study of heart mitochondria and glycolytic metabolism in experimentally induced cardiac failure. Circulat. Res. 1962, 10, 321.

12. Feinstein, M. B. Effects of experimental congestive heart failure, ouabain, and asphyxia on the highenergy phosphate and creatine content of the guinea pig heart. Circulat. Res. 1962, 10, 333.

13. Fox, A. C., N. S. Wikler, and G. E. Reed. High energy phosphate compounds in the myocardium during experimental congestive heart failure. $\mathrm{Pu}$ rine and pyrimidine nucleotides, creatine, and creatine phosphate in normal and in failing hearts. J. clin. Invest. 1965, 44, 202.

14. Argus, M. F., J. C. Arcos, V. M. Sardesai, and J. L. Overby. Oxidative rates and phosphorylation in sarcosomes from experimentally-induced failing rat heart. Proc. Soc. exp. Biol. (N. Y.) 1964, 117, 380.

15. Meerson, F. Z., T. A. Zaletayeva, S. S. Lagutchev, and M. G. Pshennikova. Structure and mass of mitochondria in the process of compensatory hyperfunction and hypertrophy of the heart. Exp. Cell Res. 1964, 36, 568.

16. Plaut, G. W. E., and M. M. Gertler. Oxidative phosphorylation studies in normal and experimentally produced congestive heart failure in guinea pigs: a comparison. Ann. N. Y. Acad. Sci. 1959, 72, 515.

17. Olson, R. E. Abnormalities of myocardial metabolism. Circulat. Res. 1964, 15 (suppl. 2), 109.

18. Morrow, A. G., W. D. Clark, D. C. Harrison, and E. Braunwald. Prosthetic replacement of the mitral valve. Operative methods and the results of preoperative and postoperative hemodynamic assessments. Circulation 1964, 29 (suppl. 1), 2.

19. Hatefi, Y., P. Jurtshuk, and A. G. Haavik. Studies on the electron transport system. XXXII. Respiratory control in beef heart mitochondria. Arch. Biochem. 1961, 95, 148.

20. Gornall, A. G., C. J. Bardawill, and M. M. David. Determination of serum proteins by means of the biuret reaction. J. biol. Chem. 1949, 177, 751.

21. Weinbach, E. C. Stability of oxidative phosphorylation and related reactions in isolated liver mitochondria. J. biol. Chem. 1959, 234, 1580.

22. Fiske, C. H., and Y. Subbarow. The colorimetric determination of phosphorus. J. biol. Chem. 1925, $66,375$.

23. Chappell, J. B. The oxidation of citrate, isocitrate and cis-aconitate by isolated mitochondria. Biochem. J. 1964, 90, 225.

24. Chance, B. Quantitative aspects of the control of oxygen utilization in Ciba Foundation Symposium on the Regulation of Cell Metabolism, G. E. W. Wolstenholme and C. M. O'Connor, Eds. Boston, Little, Brown, 1959, p. 91.
25. Wollenberger, A., E. G. Krause, and B. E. Wahler. Orthophosphat- und Phosphokreatingehalt des Herzmuskels. Naturwissenschaften 1958, 45, 294.

26. Furchgott, R. F., and T. de Gubareff. The high energy phosphate content of cardiac muscle under various experimental conditions which alter contractile strength. J. Pharmacol. exp. Ther. 1958, 124, 203.

27. Caulfield, J. B. Effects of varying the vehicle for $\mathrm{OsO}_{4}$ in tissue fixation. J. biophys. biochem. Cytol. 1957, 3, 827.

28. Lardy, H. A., D. Johnson, and W. C. McMurray. Antibodies as tools for metabolic studies. I. A survey of toxic antibiotics in respiratory, phosphorylative and glycolytic systems. Arch. Biochem. 1958, 78, 587.

29. Huxley, H. E., and J. Hanson. The molecular basis of contraction in cross-striated muscles in Structure and Function of Muscle, G. H. Bourne, Ed. New York, Academic Press, 1960, p. 205.

30. Katz, L. N., H. Feinberg, and A. B. Shaffer. Hemodynamic aspects of congestive heart failure. Circulation 1960, 21, 95.

31. Zierler, K. L. Theory of the use of arteriovenous concentration differences for measuring metabolism in steady and non-steady states. J. clin. Invest. 1961, 40, 2111.

32. Bing, R. J., C. Wu, and S. Gudbjarnason. Mechanism of heart failure. Circulat. Res. 1964, 15 (suppl. 2), 64.

33. Racker, E. Mechanisms of synthesis of adenosine triphosphate. Advanc. Enzymol. 1961, 23, 323.

34. Procita, L., A. Schwartz, and K. S. Lee. Oxidative phosphorylation in the failing dog heart-lung preparation. Circulat. Res. 1965, 16, 391.

35. Wollenberger, A., and W. Schulze. Mitochondrial alterations in the myocardium of dogs with aortic stenosis. J. biophys. biochem. Cytol. 1961, 10, 285.

36. Wollenberger, A., B. Kleitke, and G. Raabe. Some metabolic characteristics of mitochondria from chronically overloaded, hypertrophied hearts. Exp. molec. Path. 1963, 2, 251.

37. Sonnenblick, E. H., H. M. Spotnitz, and D. Spiro. Role of the sarcomere in ventricular function and the mechanism of heart failure. Circulat. Res. 1964, 15 (suppl. 2), 70.

38. Szekeres, L., and M. Schein. Cell metabolism of the overloaded mammalian heart in situ. Cardiologia (Basel) 1959, 34, 19.

39. Greiner, T. The relationship of force of contraction to high-energy phosphate in heart muscle. J. Pharmacol. exp. Ther. 1952, 105, 178.

40. Chidsey, C. A., E. H. Sonnenblick, A. G. Morrow, and E. Braunwald. Norepinephrine stores and contractile force of muscles from the failing human heart. Circulation. In press.

41. Meerson, F. Z. Compensatory hyperfunction of the heart and cardiac insufficiency. Circulat. Res. 1962. $10,250$. 